\title{
선천 긴속눈썹증
}

\section{Congenital Trichomegaly of the Eyelashes}

\author{
조상일 ${ }^{1} \cdot$ 유인천 ${ }^{1,2,3} \cdot$ 조남천 ${ }^{1,2,3} \cdot$ 안 민 $^{1,2,3}$ \\ Sang Il Cho, MD ${ }^{1}$, In Cheon You, MD, PhD ${ }^{1,2,3}$, Nam Chun Cho, MD, PhD ${ }^{1,2,3}$, Min Ahn, MD, PhD ${ }^{1,2,3}$ \\ 전북대학교 의학전문대학원 안과학교실, 전북대학교 임상의학연구소 ${ }^{2}$, 전북대학교병원 의생명연구원 ${ }^{3}$ \\ Department of Ophthalmology, Jeonbuk National University Medical School ${ }^{l}$, Jeonju, Korea \\ Research Institute of Clinical Medicine of Jeonbuk National University ${ }^{2}$, Jeonju, Korea \\ Biomedical Research Institute of Jeonbuk National University Hospital ${ }^{3}$, Jeonju, Korea
}

Purpose: To report a case of congenital trichomegaly.

Case summary: A 7-year-old girl visited our clinic with decreased visual acuity. The uncorrected visual acuity was 0.2 in the right eye and 0.3 in the left eye. The length and number of upper and lower eyelashes were increased. The eyelash length was $10 \mathrm{~mm}$ on the peripheral edge and $15 \mathrm{~mm}$ in the central area. Trichiasis and ptosis were also noted. There were no abnormal findings in the additional fundus examination or visual evoked potential test. There was no family history of trichomegaly, no abnormalities in blood test results, and no medication history. The patient is currently undergoing follow-up treatment for low visual acuity and mild ptosis under the diagnosis of trichomegaly.

Conclusions: Trichomegaly is associated with family history, various congenital diseases, and acquired diseases. However, it may occur congenitally, without specific causes.

J Korean Ophthalmol Soc 2021;62(2):285-288

Keywords: Congential disease, Eyelashes, Trichomegaly

긴속눈썹증은 1944 년 $\mathrm{Gray}^{1}$ 가 림프종 환자의 비정상적 으로 긴 속눈썹에 대하여 서술하면서 처음 보고하였다. 최 근의 여러 보고에서 속눈썹길이 증가 뿐만 아니라 구부러 짐의 증가, 색소침착의 증가, 두께 증가 또한 긴속눈썹증의 특징으로 보고되었으며 속눈썹의 길이가 중심부 $12 \mathrm{~mm}$, 주변부 $8 \mathrm{~mm}$ 이상으로 알려져 있다. ${ }^{2-5}$ 속눈썹의 성장주기 는 대략 5-6개월 지속되며, 30일의 생장기(Anagen), 15 일의

- Received: 2020. 5. 14.

- Revised: 2020. 6. 22.

- Accepted: 2021. 1. 23.

- Address reprint requests to Min Ahn, MD, PhD Department of Ophthalmology, Chonbuk National University Hospital, \#20 Geonji-ro, Deokjin-gu, Jeonju 54907, Korea

Tel: 82-63-250-1965, Fax: 82-63-250-1960

E-mail:ahnmin@jbnu.ac.kr

* Conflicts of Interest: The authors have no conflicts to disclose.
퇴행기(Catagen), 100 일 이상의 휴지기(Telogen)로 구성된 다. ${ }^{3}$ 두피털과 달리 속눈썹은 생장기의 모낭의 비율이 휴지 기 모낭의 비율보다 낮으며 두피털은 $85-90 \%$ 가 생장기인 데 반해 속눈썹은 $50 \%$ 정도만 생장기이다., ${ }^{3,6}$ 긴속눈썹증 발생시 심리적으로 방해가 될 수 있고 시력저하, 안검하수 가 생길 수 있으며 속눈썹증 발생시 각막 찰과상이 생길 수 있다. ${ }^{2,7-9}$ 긴속눈썹증의 원인들은 선천성 요인, 후천성 요인, 약물에 의한 외인적 요인으로 분류되며 다양한 증례들이 보고되어 있다. ${ }^{10}$ 국내에서는 $\mathrm{Na}$ et $\mathrm{al}^{11}$ 이 항암치료를 위해 사용된 표피성장인자 수용체 억제제로 유발된 긴속눈썹증 2예를 보고한 바 있으나 아직까지 특별한 유발 원인 없이 발생한 긴속눈썹증에 대하여 국내에서 발표된 적은 없다. 본 저자들은 유발 원인이 없는 선천 긴속눈썹증을 경험하 였기에 이를 보고하고자 한다. 


\section{증례보고}

7세 여아가 영, 유아 검진에서 발견된 시력저하를 주소로 내원하였다. 내원 당시 나안시력은 우안 0.2 , 좌안 0.3 이었 으며 안압은 우안 $14 \mathrm{mmHg}$, 좌안 $15 \mathrm{mmHg}$ 로 측정되었
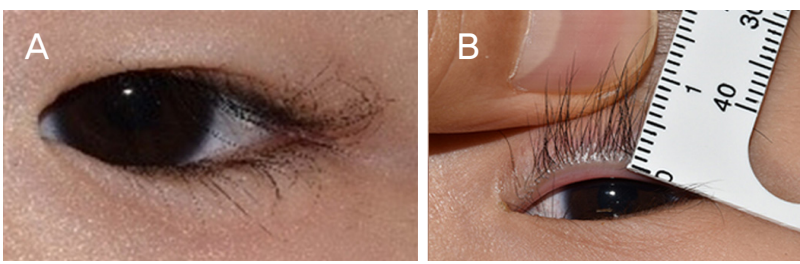

Figure 1. External photo of 7-year-old female patient. (A) External photo shows long, curled, thick eyelashes of essential trichomegaly patient. (B) On cutaneous examination, the measurement of both eyelashes reached $10 \mathrm{~mm}$ on the peripheral edge and $15 \mathrm{~mm}$ in the central area.
다. 굴절검사에서 우안 $+4.75 \mathrm{Dsph}-4.00 \mathrm{Dcyl}$, 좌안 +2.50 Dsph -4.75 Dcyl로 교정시력은 우안 0.4, 좌안 0.5였다. 상 안검, 하안검의 현저한 속눈썹의 길이 및 수의 증가가 관찰 되었으며, 두께 및 구부러짐의 증가도 관찰되었다. 속눈썹 증, 안검하수 소견도 확인되었다. 눈금자로 측정해본 결과, 양안의 속눈썹 길이는 주변부에서 약 $10 \mathrm{~mm}$ 였으며 중심부 는 $15 \mathrm{~mm}$ 였다(Fig. 1). 안저검사에서 정상 소견을 보였으 며, 시유발전위검사에서 이상 소견은 보이지 않았다. 긴속 눈썹증의 가족력도 없어 특별한 유발 요인이 존재하지 않 는 선천 긴속눈썹증으로 진단하였다. 환자는 현재 경도의 약시 및 안검하수로 경과 관찰 중이다.

\section{고 찰}

긴속눈썹증은 다양한 원인들에 의해서 발생하는 것으로 알려져 있으며 이에 대하며 Table 1에 정리하였다. ${ }^{5,10}$ 선천

Table 1. Causes of trichomegaly

\begin{tabular}{|c|c|}
\hline Condition & Features \\
\hline \multicolumn{2}{|l|}{ Congenital } \\
\hline Aghaei-Dastgheibsyndrome & Generalized hypertrichosis, bilateral nipple retraction, unilateral left-sided accessory nipple \\
\hline Cone-rod dystrophy & Retinal dystrophy, visual impairment, photophobia, foveal atrophy, hypertrichosis \\
\hline Congenital polycoria & Family history of congenital cataracts \\
\hline Cornelia de Lange syndrome & $\begin{array}{l}\text { Proportionate small stature, specific facial featrues, malformation in the musculoskeletal, cardiac, } \\
\text { neurological, and gastrointestinal systems }\end{array}$ \\
\hline Familial trichomegaly & Mutation in the FGF5 gene, oculocutaneous albinism, increased length of forearm hair \\
\hline Goldstein-Hutt syndrome & Cataracts, hereditary spherocytosis \\
\hline Hermansky-Pudlak syndrome & $\begin{array}{l}\text { Oculocutaneous albinism, congenital nystagmus, decreased visual acuity, iris trans illumination, mu- } \\
\text { tation of HPS1 gene }\end{array}$ \\
\hline Oliver-McFarlane syndrome & $\begin{array}{l}\text { Dwarfism, pigmentary degeneration of the retina, mental retardation, hypothyroidism, hypogonad- } \\
\text { ism, delayed bone age, ataxia, alopecia, mutation of PNPLA6 gene }\end{array}$ \\
\hline Phylloid hypomelanosis & Hypomelanosis, mosaic trisomy 13 , hypopigmented leaf-like macules \\
\hline Congenital heart disease & $\begin{array}{l}\text { Tetralogy of Fallot, growth and developmental delay, hypertrichosis (Inner arms, shoulders, back, } \\
\text { buttocks) }\end{array}$ \\
\hline \multicolumn{2}{|l|}{ Acquired disease } \\
\hline Alopecia areata & Remission of alopecia followed by remission of trichomegaly \\
\hline Atopic dermatitis & Several cases associated with congenital hypotrichosis \\
\hline Cancer & Adenocarcinoma of the kidney \\
\hline Dermatomyositis & Case presented with a periorbital purplish red heliotropic rash, diffuse scaling and dryness of the skin \\
\hline HIV/AIDS & Trichomegaly associated with late stage \\
\hline Systemic lupus erythematosus (rare) & Case also presented with psychosis and diffuse alopecia \\
\hline Uveitis & Cases presented with have longer eyelashes \\
\hline Vernal keratoconjunctivitis & Upper eyelashes significantly longer in the patient with vernal keratoconjunctivitis \\
\hline \multicolumn{2}{|l|}{ Drug } \\
\hline Cylosporin A, tacrolimus & Immunosuppressive immunophilin ligands \\
\hline Erlotinib, gefitinib & Tyrosine kinase inhibitors, EGFR inhibitors \\
\hline Interferon $\alpha 2 \mathrm{a}$ and $\alpha 2 \mathrm{~b}$ & Cytokines \\
\hline Bimatoprost, latanoprost, travoprost & Prostaglandin analogues \\
\hline Topiramate & Anticonvulsant \\
\hline Zidovudine & Antiretroviral \\
\hline Cetuximab, panitumumab & Monoclonal antibodies, inhibit EGFR signaling \\
\hline
\end{tabular}

HIV/AIDS = human immunodeficiency virus/acquired immune deficiency syndrome; EGFR = epidermal growth factor receptor. 
성 요인으로는 Aghaei-Dastgheib syndrome, 막대-원뿔세포이 상증(Cone-rod dystrophy,) 선천성 심장질환(Congenital heart disease), 코넬리아디란지증후군(Cornelia de Lange syndrome), 가족성 긴속눈썹증(Familial trichomegaly), Goldstein-Hutt syndrome, 헤르만스키-푸들라크증후군(Hermansky-Pudlak syndrome), Oliver-McFarlane syndrome, Phylloid hypomelanosis가 있다. ${ }^{5,10}$ 후천성 요인으로는 원형탈모증(Alopecia areata), 아토피피부염(Atopic dermatitis), 악성종양, 피부근 육염(Dematomyositis), 후천성면역결핍증(HIV), 전신홍반 루푸스(Systemic lupus erythematosus), 포도막염, 봄철각결 막염이 있다. ${ }^{5,10}$

긴속눈썹증을 유발하는 약물들로는 사이클로스포린, 표 피성장인자 수용체 억제제(Epidermal growth factor receptor inhibitors) 중 단일클론 항체인 Cetuximab, Panitumumab, 티로신인산화효소 억제제인 Erlotinib, Gefitinib, 인터페론 알파, 프로스타글란딘 제제들(Bimatoprost, latanoprost, travoprost), Tacrolimus, Topiramate, Zidovudine 등이 있으며 각 원인들의 특징에 대하여 Table 1에 정리하였다. ${ }^{5,10}$ 이외 에도 야누스인산화효소 억제제(JAK inhibitor)인 Ruxolitinib 에 의한 긴속눈썹증도 보고되었다. ${ }^{12}$

현재까지 속눈썹 모낭에 대하여 생물학적으로 밝혀진 사 실들은 많지 않다. 임신 12주에 생기기 시작하며, 두피 모 낭과 비교되는 가장 큰 특징은 털세움근이 없고, 성장 주기 가 짧은 것이다. ${ }^{5}$ 속눈썹은 상안검에서 5-6줄, 하안검에서 3-4줄로 자라며, 숫자는 상안검에서 90-160개, 하안검에서 75-80개가 정상 범위이다. ${ }^{13,14}$ 성장주기도 다양한 연구가 보고되어 있으며 생장기는 4 주, 8 주, 10 주로 연구마다 차이 가 있게 보고되어 있다. ${ }^{5}$ 속눈썹에 대한 생물학적 이해를 위하여 다양한 분자 연구들이 시행되고 있다. 생쥐를 대상 으로 한 연구에서 $\mathrm{dkk} 2$ 유전자를 결핍시킨 생쥐에서 속눈 썹 모낭세포가 정상 위치에서 벗어나 각막을 가로질러 위 치하였으며, smad4 유전자를 제거한 생쥐에서는 두줄속눈
썹증이 관찰되었다. ${ }^{5}$ 이처럼 긴속눈썹증의 치료를 위해서 는 더 많은 생물학적 연구 및 보고가 필요한 상태이며 특별 한 원인을 동반하지 않은 본태성으로 발생하는 긴속눈썹증 의 치료도 가능할 것으로 기대된다.

\section{REFERENCES}

1) Gray H. Trichomegaly or movie lashes. Stanford Med Bull 1944;2: 157-8.

2) Lacouture ME, Boerner SA, Lorusso PM. Non-rash skin toxicities associated with novel targeted therapies. Clin Lung Cancer 2006;8 Suppl 1:S36-42.

3) Santmyire-Rosenberger BR, Albert M. Acquired trichomegaly with topiramate. J Am Acad Dermatol 2005;53:362-3.

4) Jayamanne DG, Dayan MR, Porter R. Cyclosporin-induced trichomegaly of accessory lashes as a cause of ocular irritation. Nephrol Dial Transplant 1996;11:1159-61.

5) Paus R, Burgoa I, Platt CI, et al. Biology of the eyelash hair follicle: an enigma in plain sight. Br J Dermatol 2016;174:741-52.

6) Nazareth MR, Bunimovich O, Rothman IL. Trichomegaly in a 3-year-old girl with alopecia areata. Pediatr Dermatol 2009;26:188-93.

7) Manjunatha NP, Gnanaraj L. Isolated trichomegaly causing mechanical ptosis. J Pediatr Ophthalmol Strabismus 2008;45:384.

8) Woo TL, Francis IC. Intermittent blurred vision and trichomegaly due to latanoprost. Clin Exp Ophthalmol 2001;29:272-3.

9) Casson RJ, Selva D. Lash ptosis caused by latanoprost. Am J Ophthalmol 2005;139:932-3.

10) Paul LJ, Cohen PR, Kurzrock R. Eyelash trichomegaly: review of congenital, acquired, and drug-associated etiologies for elongation of the eyelashes. Int J Dermatol 2012;51:631-46.

11) Na KH, Eom YS, Kang SY, et al. Paradoxical trichomegaly of the eyelashes during treatment with EGFR inhibitors: 2 case report. J Korean Ophthalmol Soc 2014;55:908-12.

12) Song J, Song A, Palmares T, et al. Ruxolitinib found to cause eyelash growth: a case report. J Med Case Rep 2017;11:189.

13) Montagna W, Ford DM. Histology and cytochemistry of human skin. 3. The eyelid. Arch Dermatol 1969;100:328-35.

14) Liotet S, Riera M, Nguyen H. The lashes. Physiology, structure, pathology (author's transl). Arch Ophtalmol (Paris) 1977;37:697-708. 


\section{= 국문초록 $=$}

\section{선천 긴속눈썹증}

목적: 7세 여자아이에서 발생한 긴속눈썹증 1예를 보고하고자 한다.

증례요약: 7 세 여자아이가 영유아 검진시 발견된 시력저하를 주소로 내원하였다. 내원 당시 나안시력 우안 0.2, 좌안 0.3이었으며, 양안 상, 하안검 속눈썹의 길이와 수의 증가를 보였다. 양안 속눈썹의 길이는 주변부에서 $10 \mathrm{~mm}$, 중심부에서 $15 \mathrm{~mm}$ 였다. 경도의 속눈썹의 각막찌름과 경도의 안검하수가 관찰되었으며 추가로 시행한 안저검사 및 시유발전위검사에서 특이 소견은 발견되지 않았 다. 긴속눈썹증의 가족력은 없었으며 긴속눈썹증을 일으킬 만한 특이 소견은 발견되지 않았다. 혈액검사상 이상 소견은 없었으며 특 이 약물 복용력 또한 없었다. 현재 긴속눈썹증 진단하에 경도의 시력저하 및 안검하수로 경과 관찰 중이다.

결론: 긴속눈썹증은 가족력 및 다양한 선천성 질환, 후천적 요인에 의하여 발생하는 것으로 알려져 있으나 특별한 원인 없이 선천적으 로 발생하는 경우도 있으므로 이에 대하여 주지할 필요가 있다.

〈대한안과학회지 2021;62(2):285-288〉

\section{조상일 / Sang || Cho}

전북대학교 의학전문대학원 안과학교실 Department of Ophthalmology, Jeonbuk National University Medical School

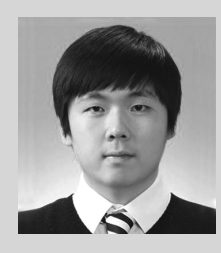

